\title{
Intestinal ameliorative effects of traditional Ogi-tutu, Vernonia amygdalina and Psidium guajava in mice infected with Vibrio cholera.
}

\author{
Olufunke B Shittu', Olusola L Ajayi ${ }^{2}$, Samuel O Bankole ${ }^{3}$, Temitope OS Popoola ${ }^{1}$
}

1. Department of Microbiology, College of Biosciences, Federal University of Agriculture, Abeokuta, Nigeria.

2. Department of Veterinary Pathology, College of Veterinary Medicine, Federal University of Agriculture, Abeokuta, Nigeria.

3. Department of Pure and Applied Zoology, College of Biosciences, Federal University of Agriculture, Abeokuta, Nigeria.

\begin{abstract}
Background: Cholera, a severe acute watery diarrhea caused by Vibrio cholerae is endemic in Nigeria with most cases occurring in the rural areas. In South West Nigeria, some individuals resort to alternative treatments such as Ogi-tutu, Psidium guajava and Vernonia amygdalina during infections. The effectiveness of these alternatives in the prevention and treatment of $V$. cholerae infection requires experimental investigation.

Objective: This study was designed to investigate the ameliorative effects of Ogi-tutu, Vernonia amygdalina and Psidium guajava on intestinal histopathology of experimental mice infected with $V$. cholerae.

Methods: Preliminary investigation of in vitro vibriocidal activities of these alternatives were carried out using agar cup diffusion assay. For ameliorative effects, adult mice were inoculated with $100 \mu \mathrm{l}$ (106 cells) of Vibrio cholerae and dosed at $0 \mathrm{~h}$ (immediate prevention) and $4 \mathrm{~h}$ (treatment of infection) and their intestines were histopathologically evaluated.

Results: The histopathological changes were the same irrespective of the treated groups, but the lesions varied in extent and severity. The ameliorative effects in decreasing order were $V$. amygdalina $>$ P. guajava $>$ Ogi-tutu.

Conclusion: $V$. amygdalina gave the best ameliorative effects in the prevention and treatment of $V$. cholerae infection.

Keywords: Vibrio cholerae, Ogi-tutu, Psidium guajava, Vernonia amygdalina.

DOI: http://dx.doi.org/10.4314/ahs.v16i2.33

Cite as: Shittu OB, Ajayi OL, Bankole SO, Popoola TOS. Intestinal ameliorative effects of traditional Ogi-tutu, Vernoniaamygdalina and psidiu guajava in mice infected with Vibrio cholera. Afri Health Sci 2016;16(2): 620-628. bttp:/ / dx.doi.org/ 10.4314/abs.v16i2.33
\end{abstract}

\section{Introduction}

Vibrio cholerae is a human pathogen that causes a severe acute watery diarrhea called cholera, a waterborne disease characterized by severe dehydration ${ }^{1,2}$. Vibrio cholerae is a major public health problem because of its epidemic potential ${ }^{3}$. Though, there are approximately 200 serotypes, only $V$. choleare $\mathrm{O} 1$ and $\mathrm{O} 139$ have been found in epidemic and pandemic cholera ${ }^{4}$. Without treatment, the case fatality rate for severe cholera can be as high as $50 \%{ }^{5}$.
Corresponding author,
Olufunke B Shittu,
Department of Microbiology,
College of Biosciences,
Federal University of Agriculture,
Abeokuta, Nigeria
Tel: +234-803-353-2640
Email: olufunke_b@yahoo.com

Nigeria is in one of the three major cholera foci in the world, with frequent outbreaks and epidemics from different parts of the country ${ }^{6}$. In SouthWest Nigeria, majority of the people living in rural areas use traditional medicines to treat all types of diarrhea ${ }^{7}$ This is in line with the World Health Organization (WHO) estimates of approximately $80 \%$ of the world's inhabitants that rely on traditional or herbal medicines for their primary health care $^{8}$.

Regarded as traditional remedy for diarrhea and specifically for the treatment of cholera, is the use of "ogi-tutu" and this is acclaimed to stop the characteristic cholera symptoms. Ogi-tutu is the wet cake mixed with omidun (sour-water) $^{9-10}$. Ogi is a porridge prepared from fermented maize, sorghum or millet in West Africa ${ }^{11}$. Ogi may have potentials for treatment of diarrhea, due to its high level of lactic acid bacteria $(\mathrm{LAB})^{10}$.

Also, several plants are used locally in the treatment of diarrhoea $^{11-14}$. Psidium guajava L. and Vernonia amygdalina ${ }^{15-16}$ 
are two of such plants that are used in SouthWest Nigeria. Vernonia amygdalina is a dark green vegetable known as bitter leaf in English, and ewuro in Yoruba land ${ }^{17}$. The roots and leaves are used in phytomedicine to treat fever, hiccups, kidney disease and stomach discomfort, and as antihelminthic and antimalarial ${ }^{13}$. Psidum guajava $\mathrm{L}$. commonly known as guava of the family Myrtaceae is a plant used in the indigenous system of medicine for the treatment of various human ailments such as wounds, ulcers, bowels and cholera ${ }^{18}$. The plant is also known for its antidiabetics, antispamodic, antidiarrheal and antidysentary properties ${ }^{19-20}$. Empirical proof of these traditional treatments in ameliorating histopathological effects of Vibrio cholerae in the intestinal mucosa need to be investigated.

\section{Methods}

\section{Study design}

A randomized controlled experimental design was used in this study. Ethical approval for the study was obtained from the Research and Ethical Committee, Department of Microbiology, College of Biosciences, Federal University of Agriculture, Abeokuta, Nigeria through Research Proposal Presentation and Approval (Approval number: 2005/06/01/01) .

\section{Vibrio cholerae strains}

Toxigenic strain of $V$. cholerae isolated from an epidemic case in Nigeria was used for the study. A loopful of the working stock was transferred into $3 \mathrm{ml}$ Tryptone Soy Broth (TSB, Oxoid) containing $\mathrm{NaCl}$ at final concentration of $3 \%\left(\mathrm{Na}-\mathrm{TSB}\right.$ broth) and incubated at $37^{\circ} \mathrm{C}$ for 18 h. Before inoculation, $V$. cholerae was grown in Luria Ber-

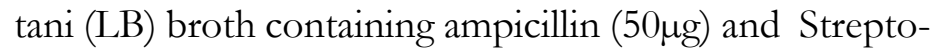
mycin $(50 \mu \mathrm{g})$ at $37^{\circ} \mathrm{C}$ on a roller shaker for 16 to $18 \mathrm{hrs}$.

\section{Preparation of Ogi-tutu}

Corn-Ogi, was prepared by spontaneous traditional fermentation. Ogi slurry was prepared by adding $100 \mathrm{ml}$ of sour water (omidun) to $50 \mathrm{~g}$ of ogi cake and then, mixed thoroughly. A hundred milliliters $(100 \mathrm{ml})$ slurry of ogi was measured into sterile $250 \mathrm{ml}$ Erlenmeyer flask. Before inoculation, the ogi slurry samples were maintained at experimental temperature $\left(37^{\circ} \mathrm{C}\right)$ for 1 to $2 \mathrm{hrs}$ to allow for equilibration ${ }^{21}$.

\section{Source of Vernonia amygdalina extract and Psidium guajava decoction}

Fresh leaves of each plant were purchased from herb sellers at Itoku market in Abeokuta, Ogun State, Nigeria. Voucher specimens were taken to the Herbarium Unit of the Department of Forestry and Wildlife Management, Federal University of Agriculture, Abeokuta. Vernonia amygdalina was classified as Asteraceae Grp 1 and Psidum guajava L. as Myrtaceae Grp 1. Herbarium sample specimens were deposited with voucher numbers FUNAAB/ FWM/HU/Asteraceae 1/005 and FUNAAB/FWM/ HU/Myrtaceae 1/030.

\section{Traditional Preparation of Vernonia amygdalina ex- tract and Psidium guajava decoction}

Raw extract of Vernonia amygdalina was obtained by crushing $100 \mathrm{~g}$ using sterile mortar and pestle. Decoction of Psidium guajava was prepared by boiling $100 \mathrm{~g}$ of the shade dried leaves in $100 \mathrm{ml}$ distilled water till the volume was reduced to $25 \mathrm{ml}$. The resulted extracts were centrifuged and filtered through a membrane of $0.22 \mu \mathrm{m}$ pore size before use for investigation.

\section{Procedure for ethanolic extraction of Vernonia amygdalina and Psidium guajava}

The leaves were dried at $40^{\circ} \mathrm{C}$ in the hot-air oven, powdered and stored in an airtight container for use. The powders were then soaked in 50\% redistilled (aqueous) ethanol in a glass container for $48 \mathrm{~h}$. This was followed by filtration. The filtrate was concentrated to dryness using water bath at $40^{\circ} \mathrm{C}$ and finally in a dessicator unit.

\section{Preliminary vibriocidal activity by agar diffusion cup plate assay \\ Agar diffusion method was used to evaluate the vibri- ocidal activity of the extracts using $100 \mu \mathrm{l}$ of extracts. Diameters of zones of inhibition were measured to the nearest millimeter.}

\section{Oral inoculation of mice}

Adult mice (7 to 10 weeks old) were purchased from the Department of Veterinary Physiology, University of Ibadan, Nigeria and transported to the experimental unit of the Department of Pure and Applied Zoology, College of Biosciences, Federal University of Agriculture, 
Abeokuta, Nigeria where they were left to acclimatize for $72 \mathrm{hrs}$. During the period of acclimatization, animals were treated by following strictly, the principles of laboratory animal care" (NIH Publication No. 85-23) and mice were fed with pelleted feed and water ad libitum.

Prior to $V$. cholerae inoculation, the animals were fasted for $24 \mathrm{hrs}$ prior to the experiment and were randomly divided into ten groups, with three animals per group. Eight groups were inoculated orally with $100 \mu \mathrm{l}$ (106 cells) of toxigenic $V$. cholerae via syringe while the ninth and tenth group served as uninoculated control group. Out of the eight inoculated groups, only six were dosed with ogi-tutu $(500 \mathrm{mg} / \mathrm{ml})$, ethanolic extracts of P. guajava (250 $\mathrm{mg} / \mathrm{kg}$ ) and $V$. amygdalina $(250 \mathrm{mg} / \mathrm{kg})$, three groups at 0 hrs (immediate prevention) and three groups at 4 hours (treatment of infection). The remaining two untreated groups were given only distilled water and they served as infected but not treated positive control. Each treated group of animal was monitored for $24 \mathrm{~h}$ after which they were sacrificed. However, the uninfected control group (negative control) was sacrificed at $0 \mathrm{hrs}$ and $4 \mathrm{hrs}$ for histopathological comparison. Also, the infected but untreated group (positive control) at $0 \mathrm{hrs}$ was also sacrificed immediately while the delayed group was sacrificed after 24 hrs.

The summary of the experimental treatment groups: Group 1: Inoculated orally with $V$. cholerae; dosed with Ogi-tutu at 0 hrs; sacrificed at $24 \mathrm{hrs}$

Group 2: Infected with $V$. cholerae; dosed with Ogi-tutu at 4 hrs; sacrificed at 24 hrs

Group 3: Infected with $V$. cholerae; dosed with $V$. amygdalina at 0 hrs; sacrificed at $24 \mathrm{hrs}$

Group 4: Infected with $V$. cholerae; dosed with $V$. amygdalina at 4 hrs; sacrificed at 24 hrs

Group 5: Infected with $V$. cholerae; dosed with P. guajava at 0 hrs; sacrificed at 24 hrs

Group 6: Infected with $V$. cholerae; dosed with P. guajava at $4 \mathrm{hrs}$; sacrificed at $24 \mathrm{hrs}$

Group 7: Infected with $V$. cholerae; untreated (positive control); sacrificed at $0 \mathrm{hrs}$

Group 8: Infected with $V$. cholerae; untreated (positive control); sacrificed at $24 \mathrm{hrs}$

Group 9: Not infected (Normal negative control); sacrificed at 0 hrs
Group 10: Not infected (Normal negative control); sacrificed at 4 hrs representing 4 hrs

\section{Routine histopathology}

Mice intestinal samples were eviscerated and harvested after 24 hour. These were immediately washed briefly in phosphate buffered saline (PBS) and then fixed in buffered $10 \%$ formalin. After $48 \mathrm{~h}$, the intestinal tissues were trimmed and dehydrated in graded levels of alcohol $(50 \%$, $70 \%, 80 \%$ and $100 \%$ ) and cleared in two changes of xylene. Tissues were embedded in paraffin wax, sectioned at $5 \mu \mathrm{m}$ and stained with haematoxylin and eosin stains. The stained specimens were further dehydrated in graded levels of ethanol and cleared in xylene. The photomicrographs of the tissues were viewed and taken under light microscope (Leica, UK).

The degree of intestinal histopathological changes were semi-quantified depending on the severity and distribution of the intestinal lesions. Histopathological changes such as degeneration and necrosis of enterocytes, inflammatory cellular infiltration in the lamina propria, regeneration of enterocytes, stumpy and club-shaped villi and goblet cell hyperplasia were scored or assigned as follows: $(-)=$ absent, $(+)=1$ to 4 foci/section examined, $(++)=5$ to 8 foci/section examined $(+++)=>9$ foci $/$ section examined.

\section{Results}

\section{Preliminary investigation of vibriocidal activities}

The three traditional treatment proved effective at preliminary investigation as displayed in clear halos of growth inhibition of Vibrio cholerae. Also, both the traditional and $50 \%$ ethanolic extracts of $V$. amygdalina and P. guajava exhibited similar inhibitory activities.

\section{Histopathology of Ogi-tutu, Psidium guajava and V. amygdalina}

The histopathological changes were the same irrespective of the treated groups, but the lesions varied in extent and severity. Table 1 shows that at zero and fourth hour p.i., animals treated with ogi tutu showed moderate diffuse degenerative and inflammatory changes with most of the exudate made up of neutrophils and few lymphocytes. 
Table 1: Semi-quantification of the intestinal histopathological changes of Vibrio cholerae infection treated with local herbs at zero and $4^{\text {th }}$ hours in mice after 24 hour post infection

\begin{tabular}{|c|c|c|c|c|c|c|c|c|c|c|}
\hline & \multicolumn{2}{|c|}{ Ogi-tutu } & \multicolumn{2}{|c|}{$\begin{array}{l}P . \\
\text { guajava }\end{array}$} & \multicolumn{2}{|c|}{$\begin{array}{l}\text { Vernonia } \\
\text { amygdalina }\end{array}$} & \multicolumn{2}{|c|}{$\begin{array}{l}\text { Infected but } \\
\text { untreated } \\
\text { (Positive control) }\end{array}$} & \multicolumn{2}{|c|}{$\begin{array}{l}\text { Not infected } \\
\text { (Negative control) }\end{array}$} \\
\hline Lesions & $\mathrm{IM}_{0} \mathrm{~h}$ & $\mathrm{DE}_{4} \mathrm{~h}$ & $\mathrm{IM}_{0} \mathrm{~h}$ & $\mathrm{DE}_{4} \mathrm{~h}$ & $\mathrm{IM}_{0} \mathrm{~h}$ & $\mathrm{DE}_{4} \mathrm{~h}$ & $\mathrm{IM}_{0} \mathrm{~h}$ & $\overline{\mathrm{DE}_{4} \mathrm{~h}}$ & $\mathrm{IM}_{0} \mathrm{~h}$ & $\mathrm{DE}_{4} \mathrm{~h}$ \\
\hline $\begin{array}{l}\text { Degeneration } \\
\text { and necrosis of } \\
\text { enterocytes }\end{array}$ & ++ & ++ & - & + & - & + & +++ & +++ & - & - \\
\hline $\begin{array}{l}\text { Inflammatory } \\
\text { exudates in the } \\
\text { lamina propria }\end{array}$ & ++ & ++ & - & + & + & - & +++ & +++ & - & - \\
\hline $\begin{array}{l}\text { Regeneration of } \\
\text { enterocytes }\end{array}$ & - & - & ++ & ++ & + & + & + & + & - & - \\
\hline $\begin{array}{l}\text { Stumpy and } \\
\text { club-shaped } \\
\text { villi }\end{array}$ & ++ & ++ & + & ++ & + & + & +++ & +++ & - & - \\
\hline $\begin{array}{l}\text { Goblet cells } \\
\text { hyperplasia }\end{array}$ & - & - & + & + & + & ++ & ++ & ++ & + & + \\
\hline
\end{tabular}

$I M_{0} h=$ Immediate treatment at zero hour(prevention), $\quad D E_{4} h=$ Delayed treatment at 4 hours (treatment of infection); - = absent; $+=$ mild $;++=$ Moderate; $+++=$ Marked

The villi were stumpy and club-shaped in appearance with mild goblet cells hyperplasia (Plate 1). 


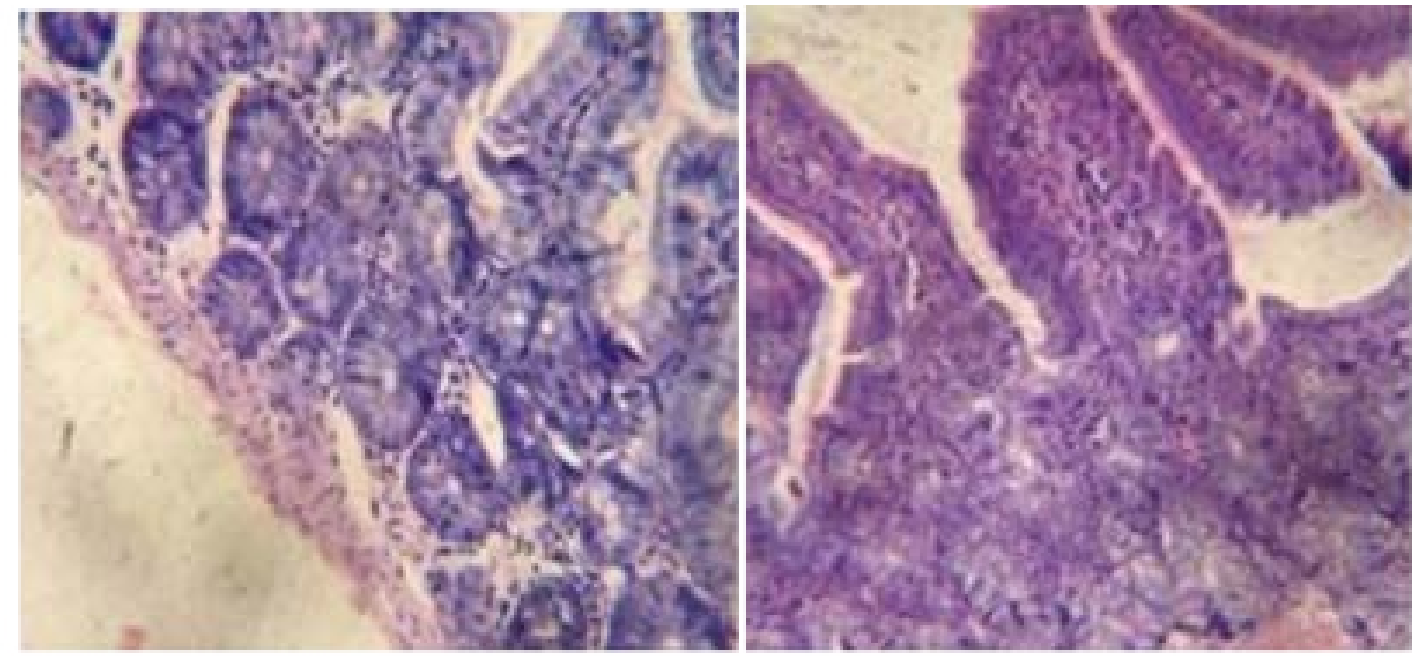

Plate1A = Photomicrograph of intestine at $0 \mathrm{hr}$ of Ogi tutu showing degencration and necrosis of intestinal cpithelial cells and mild mononuclear ccllular infiltration in the lamina propria. Haematoxylin \& Eosin. Bar $=150$ um.

Plate $1 \mathrm{~B}=$ Photomicrograph of intestine at $4 \mathrm{hr}$ of Ogi wutu showing marked diffuse necrosis and degencration of epithelial cells and the crypt of licberkuhn with cellular infiltration in the lamina propria. Hacmatoxylin \& liosin. Bar $=150 u m$

Tissues treated with Psidium guajava (Plate 2) and $V$. amygdalina (Plate 3) demonstrated marked anti-inflammatory and anti secretory properties at both zero and $4^{\text {th }}$ hour p.i, evidenced by the very mild degenerative and inflam- matory changes with mild goblet cells proliferation in the intestinal mucosa of the groups treated with these plants. The anti-inflammatory and anti-secretory activities were more prominent in $V$. amygdalina and $P$. guajava compared with Ogi-tutu.

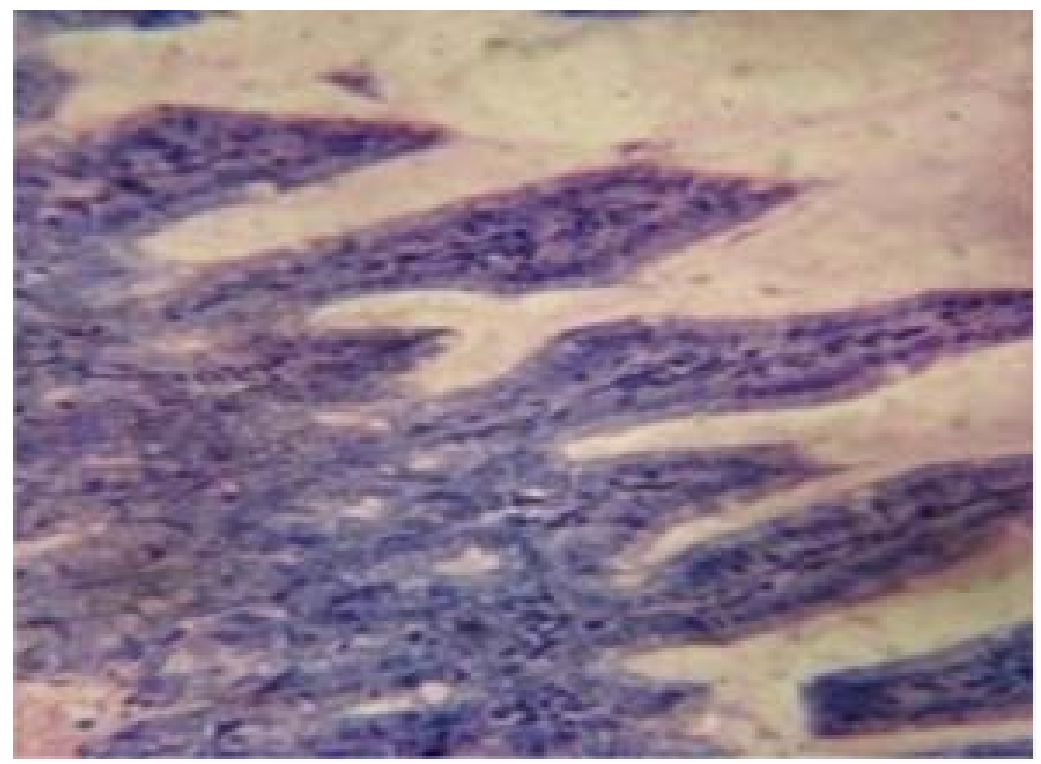

Plate 2. Photomicrograph of intestine of Psidam guajava at 4 h showing mild diffuse degeneration and necrosis with light cellular infiltration in the lamina propria. Hacmatoxylin \& Iiosin, Bar $=150_{\mu \mathrm{m}}$ 

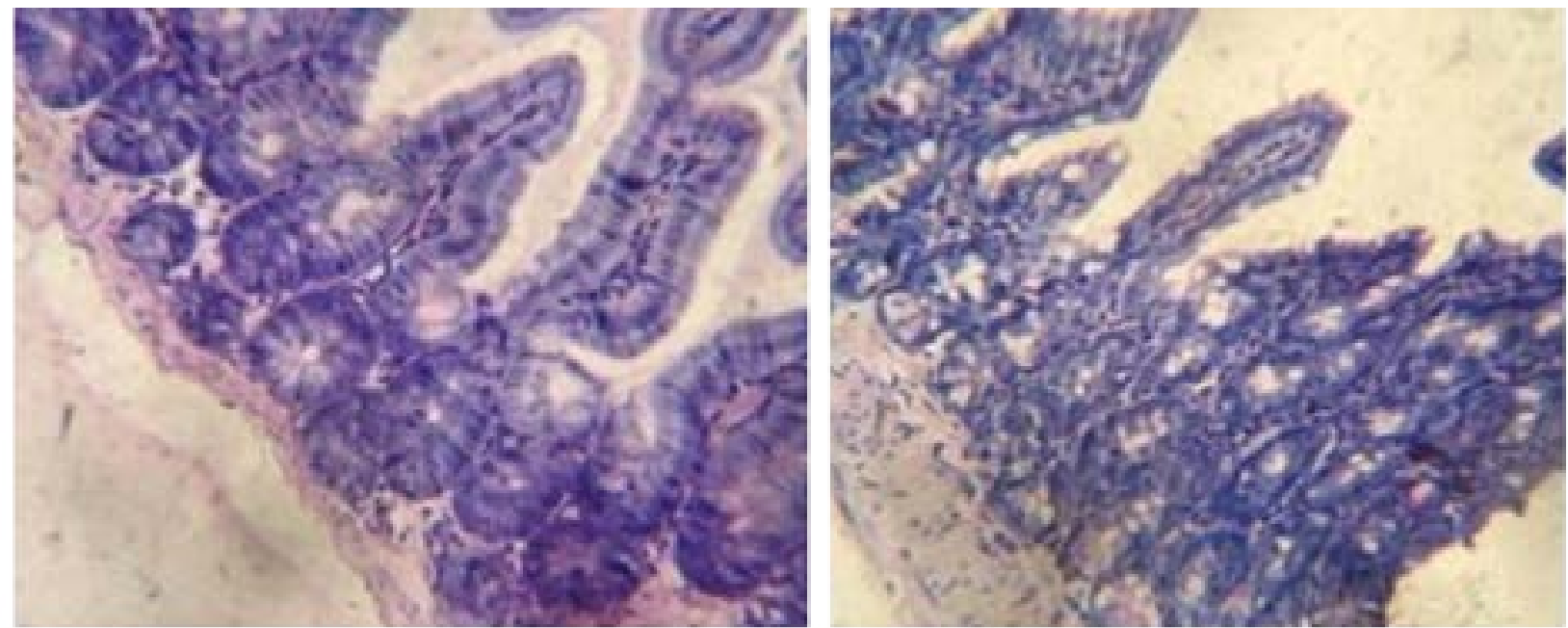

Plate. 3A $=$ Photomicrograph of intestine of $V$ emonia amgdalina at $0 \mathrm{~h}$ showingslight cellular infiltration in the lamina propra but with nomal cpithelial cells. Hacmatoxylin \& Losin. Baz $=100$ um.

$3 \mathrm{~B}=$ Photomicrograph of intestine of Vomonia amygdalina at 4 h showing moderate globlet cells hyperplasia and stumpy villi with mild cellular infiltration in the lamina propia. Hacmatoxylin \&Fosin. Bar $=150 \mu \mathrm{m}$.

The infected but untreated group (Plate 4) showed severe infiltration of the lamina propria with neutrophils and lymphocytes, proliferation and regeneration of enterocytes with stumpy and club-shaped villi in this study.

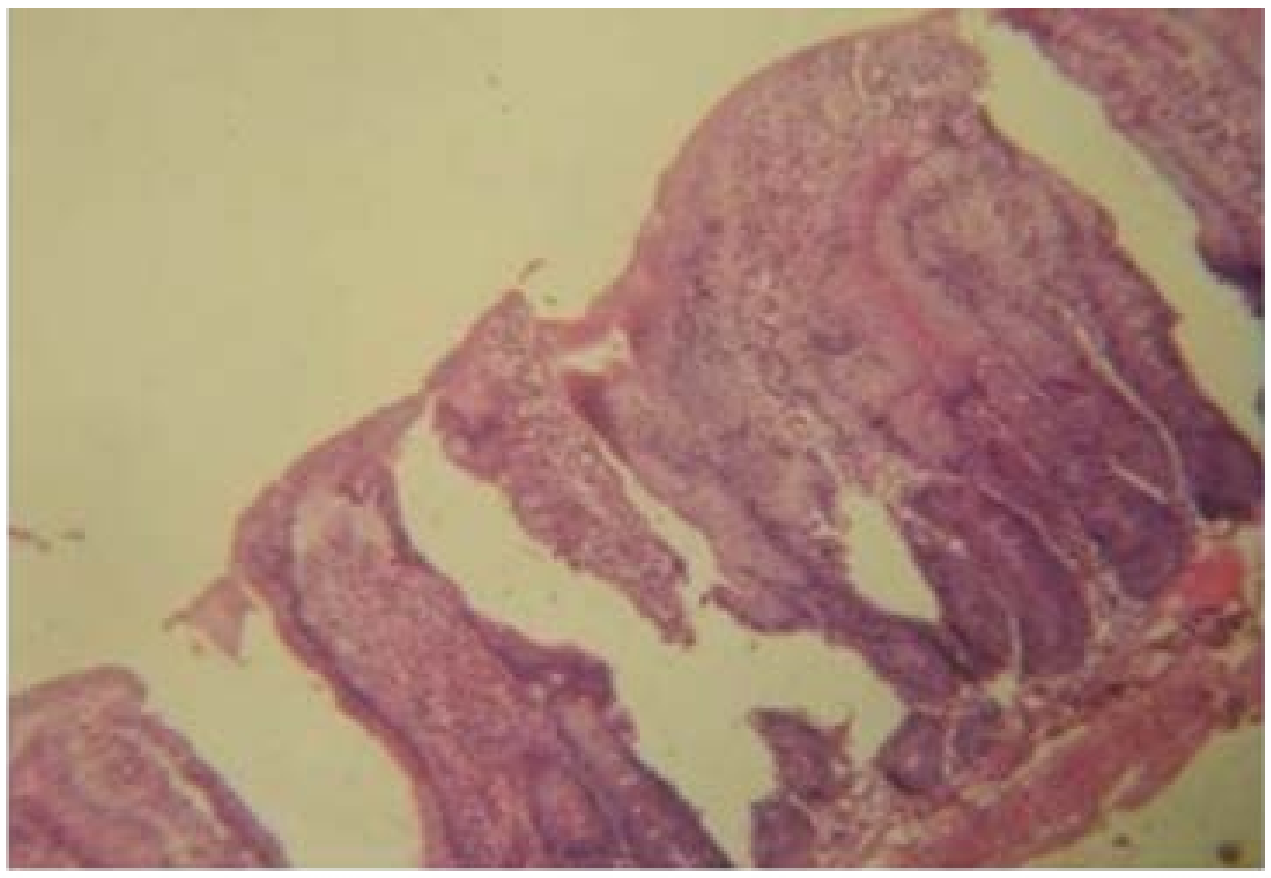

Plate 4. Photomicrograph of untreated but infected cell showing severe diffuse necrosis of the villi with marked cellular infiltration in the lamina propria. Hacmatoxylin \& Eosin. Bar $=150 \mu \mathrm{m}$ 


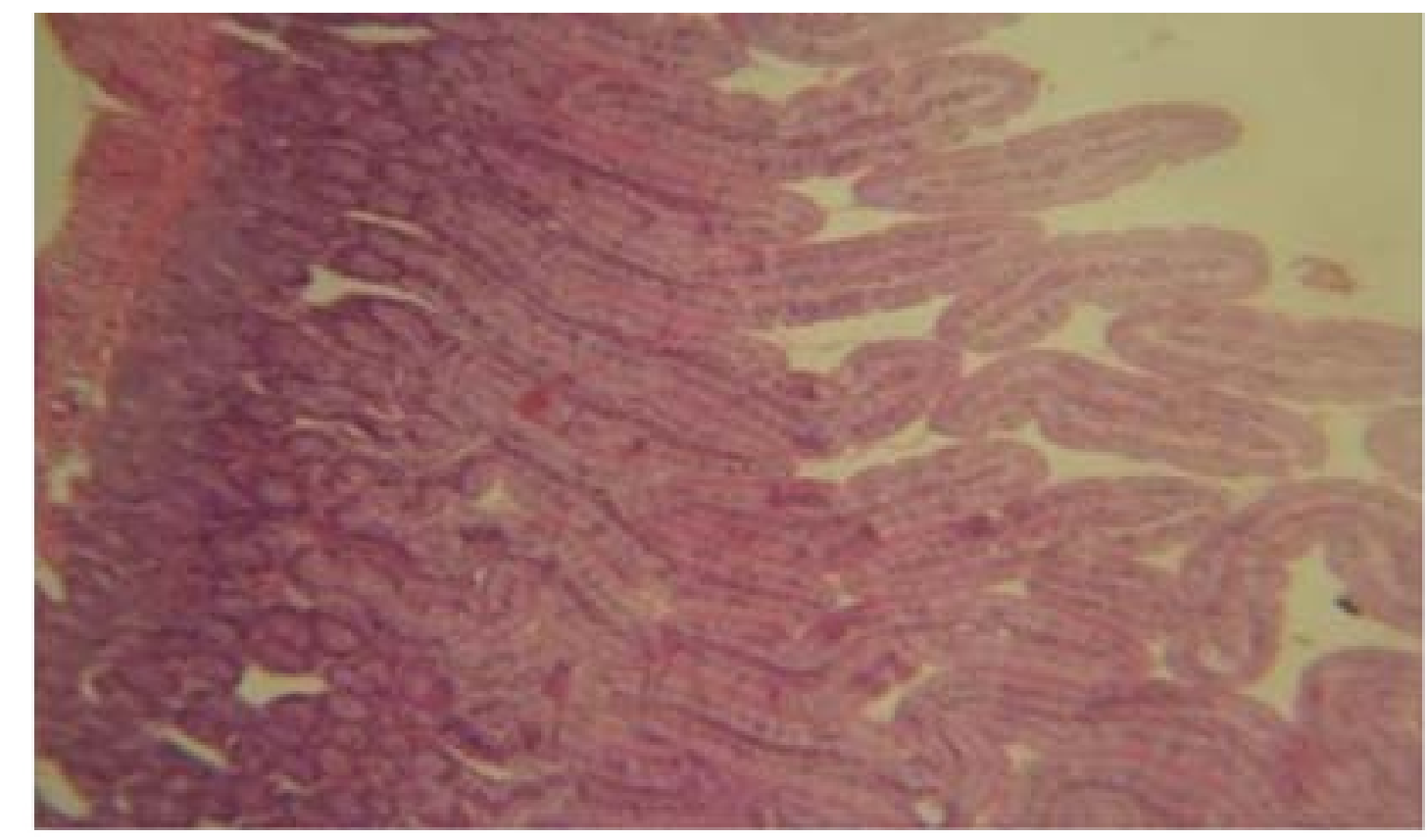

\section{Plate 5. Photomicrograph of normal uninfected intestine (control). I lacmatoxylin \& Eosin. Bar $=150 \mu \mathrm{m}$.}

\section{Discussion}

Several traditional treatments of diarrhea and specifically, cholera are in practice in SouthWestern Nigeria. These traditional claims require experimental investigation to ascertain their effectiveness. Preliminary investigation of vibriocidal activities of Ogi tutu, $V$. amygdalina and P. guajava showed in vitro vibriocidal activities. These agreed with findings on antibacterial activities documented in the literature ${ }^{16,19,22-24}$.

However, investigation on histopathological effects gave varied ameliorative effects. Ogi-tutu $(500 \mathrm{mg} / \mathrm{ml})$ was less effective in treating $V$. cholerae infection as evidenced by the moderate diffuse degenerative and inflammatory changes observed at histopathology. Ogi-tutu contain lactic acid bacteria (LAB) which have been shown to possess or have antimicrobial potentials and it is significant in the management of human clinical infections ${ }^{22-23}$.

Vernonia amygdalina showed very high preventive and effective treatment measures in both the immediate and delayed groups of mice demonstrating excellent ameliorative effect and very mild degenerative changes in vivo.
Similar antidiarrheal activity was demonstrated in castor oil induced diarrhea ${ }^{24}$. The varied biological activity of $V$. amygdalina is said to be likely due to the combination of its active compounds such as saponins and alkaloids, terpenes, steroids, coumarines, flavonoids, phenolic acids, lignans, xanthones and anthraquinones edotides, tannins and sesquiterpene lactone ${ }^{25}$.

Psidium guajava displayed very high activity as both prevention and treatment of $V$. cholerae infections when compared with positive and negative control groups. The ameliorative effects of this plant were attested to by the very mild degenerative and inflammatory changes observed in this study. Antidiarrheal activity of the leaves has been proven ${ }^{26}$ and also, of the fruit in castor oil induced diarrhea ${ }^{27}$. The decoction of the leaves is capable of neutralizing Vibrio cholerae ${ }^{28}$. Pharamacological investigation indicated that its bark, fruit and leaves posses antibacterial, hypoglycemic, anti-inflammatory, analgesic, antipyretic, spasmolytic and CNS depressant properties ${ }^{19}$.

\section{Conclusion}

Ogi-tutu displayed less ameliorative effects in the prevention and treatment of $V$. cholerae infection. However, $V$. 
amygdalina showed better ameliorative effects than P. guajava in infected mice. The ameliorative effects in decreasing order were $V$. amygdalina $>P$. guajava $>$ Ogi-tutu. Vernonia amygdalina could be used for preventive and treatment of Vibrio cholerae infection. Further investigations on the active principles of $V$. amygdalina with its mechanism of action are warranted. This might channel a new pathway and better alternative therapeutic agents in the management of diarrhea associated with $V$. cholerae.

\section{Acknowledgements}

The authors would like to appreciate the Department of Veterinary Pathology, College of Veterinary Medicine and the Department of Pure and Applied zoology, College of Biosciences, Federal University of Agriculture, Abeokuta, Nigeria, where the study was conducted.

\section{Source of funding}

Nil.

\section{Conflict of interest}

The authors declare no conflict of interest.

\section{References}

1. Talkington D, Bopp C, Tarr C, Parsons MB, Dahourou G, Freeman M, et al. Characterization of toxigenic Vibrio cholerae from Haiti, 2010-2011. Emerg Infect Dis2011; [serial on the Internet]. [19th August 2013]. http://dx.doi. org/10.3201/eid1711.110805.

2. Marin MA, Thompson CC, Freitas FS, Fonseca EL, Aboderin AO, et al. Cholera Outbreaks in Nigeria Are Associated with Multidrug Resistant Atypical El Tor and Non-O1/Non-O139 Vibrio cholerae. PLoS Negl Trop Dis 2013; 7(2): e2049. doi:10.1371/journal.pntd.0002049.

3. Piarroux R, Faucher B. Cholera epidemics in 2010: respective roles of environment, strain changes, and humandriven dissemination. Clinical Microbiology and Infection 2012; 18: 231-238. doi: 10.1111/j.1469-0691.2012.03763.x

4. Salim S, Lan R, Reeves PR. Vibrio cholerae: Pathogenic Clones. Emerging Infectious Diseases 2005; 11 (11). www.cdc.gov/eid.http://www.ncbi.nlm.nih.gov/pmc/ articles/PMC3367346/

5. Sack DA, Sack RB, Nair GB, Siddique AK. Cholera. Lancet 2004; 363: 223-233. http://www.ncbi.nlm.nih. gov/pubmed/14738797.

6. Adagbada AO, Adesida SA, Nwaokorie FO, Niemogha M-T, Coker AO. Cholera Epidemiology in Ni- geria: an overview. The Pan African Medical Journal 2012; 12: 59. http://www.ncbi.nlm.nih.gov/pubmed/22937199.

7. Shittu OB . Social and environmental risk factors of cholera and alternative approach to its prevention and treatment. Ph.D. Thesis. Federal University of Agriculture, Abeokuta, Nigeria 2009; 250pp.

8. World Health Organization. Traditional medicine. Media centre: 2008. http://www.who.int/mediacentre/ factsheet/fs/34/en.

9. Olukoya DK. Lactobacillus in human health with reference to locally fermented foods. Nig Med J 1993; 24 (1): 28-30.

10. Lei V, Friis H, Michaelson KF. Spontaneously fermented millet product as a natural probiotic treatment for diarrhea in young children: An intervention study in Northern Ghana. Int J Fd Microbiol 2006; 110: 245-253. doi:10.1016/j.ijfoodmicro.2006.04.022

11. Odunfa SA. African fermented foods. In: Microbiology of fermented foods, Vol 2, Wood BJ (ed), London \& New York: Elsevier Applied Science Publishers, 1985. 12. Sofowora A. Medicinal Plants and Traditional Medicines in Africa. New York: John Wiley \& Sons, 1993.

13. Gill LS. Ethanomedical uses of plants in Nigeria. Benin City: University of Benin Press, 1992; 276pp.

14. Olapade EO. The Herbs for Good Health. Ibadan, Nigeria: NarL Specialist Clinic, 2003; 146pp.

15. Oluwalana SA, Ezeri GNO, Bankole MO, Bamire EO. Uses of forest plants in traditional water management in Ogun State Nigeria. The Bioprospector 1999; 1 (1): 43-54.

16. Iwalokun BA, Bamiro SB, Durojaiye OO. An antimicrobial evaluation of Vernonia amygdalina (Compositae) against gram-positive and gram-negative bacteria from Lagos Nigeria. W Afri J Pharmacol Drug Res 2003; 19 (1 \& 2): 9-15.

17. Bosch CH, Borus DJ, Siemonsma JS. Vegetables of Tropical Africa. Conclusions and Recommendations Based on PROTA 2: 'Vegetables'. PROTA Foundation, Wageningen, Netherlands, 2005; 68pp.

18. Olajide OA, Awe SO, Makinde JM. Pharmacological studies on the leaf of Psidium guajava. Fitoterapia 1999; 70: 25-31.

19. Begum S, Hassan SI, Siddiqui BS, Shaheen F, Ghayur, MN, Gillani AH. Triterpenoids from the leaves of Psidium guajava. Phytochem 2002; 61: 399-403. http://www.ncbi. nlm.nih.gov/pubmed/12377233

20. Gutierrez RMP, Mitchell S, Solis RV. Psidium guajava: A review of its traditional uses, phytochemistry and phar- 
macology. Journal of Ethnopharmacology 2008; 117(1): 1-27. doi: 10.1016/j.jep.2008.01.025.

21. Dalsgaard A, Reichert P, Mortensen HF, Sandstrom A, Kofoed P-E, Larsen JL, Molbak K. Application of lime (Citrus aurantifolia) juice to drinking water and food as a cholera-preventive measure. J Fd Protec 1997; 60 (11):1329-1333.

22. Odugbemi T, Odujinrin OMT, Akitoye CO, Oyerinde, JPO, Esumeh FI. Study on the $\mathrm{pH}$ of ogi, Nigerian fermented weaning food, and its effect on enteropathogenic Escherichia coli, Salmonella typhi and Salmonella paratyphi. J Trop Med Hyg 1991; 94: 219-223.

23. Kingamkono R, Shogren E, Svanberg U, Kaijser B. Inhibition of different strains of enteropathogens in lactic acid-fermenting cereal gruel. WJ Microbiol Biotechnol 1995; 11: 299-303.

24. Okere OS, Sangodele JO, Tade OG, Obafemi OT, Falode JA. Anti-diarrhea potential and acute toxicity studies of methanolic extract of Vernonia amygdalina and Cym- bopogoncitratus against castor oil induced diarrhea model in rats. International Journal of Biochemistry Research \& Review 2015; 6(2): 46-52.

25. Erasto P, Grierson DS, Afoloyan AJ. Bioactive sesquiterpine lactones from leaves of Vernonia amygdalina. J Ethnopharmacol 2006; 106(11):117-120. http://www.ncbi. nlm.nih.gov/pubmed/16458461

26. Ezekwesili JO, Nkemdilim UU, Okeke CU. Mechanism of antidiarrhoeal effect of ethanolic extract of Psidium guajava leaves. Biokemistri 2010; 22 (2):85-90.

27. Ndukui JG, Murithi BM, Muwonge H, Sembajwe LF, Kateregga J. Antidiarrheal activity of ethanolic fruit extract of Psidium guajava (guava) in castor oil induced diarrhea in albino rats. Natl J Physiol Pharm Pharmacol 2013; 3:191-197. doi: 10.5455/njppp.2013.3.100620131

28. Birdi T, Daswani P, Brijesh S, Tetali P, Natu A, Antia N. Newer insights into the mechanism of action of Psidium guajava L. leaves in infectious diarrhea. BMC Complementary and Alternative Medicine 2010; 10:33. doi: 10.1186/1472-6882-10-33 